\title{
THE HELLENIC NATIONAL TSUNAMI WARNING CENTER: RESEARCH, OPERATIONAL AND TRAINING ACTIVITIES
}

\author{
Papadopoulos G.A. ${ }^{1}$, Tselentis G.A. ${ }^{1}$, Charalampakis M. ${ }^{1}$ and all the \\ scientific staff of the Institute of Geodynamics ${ }^{1}$
}

${ }^{1}$ Institute of Geodynamics, National Observatory of Athens, 11810, Athens, Greece, papadop@noa.gr,tselenti@noa.gr,cmarinos@noa.gr

\begin{abstract}
The Hellenic National Tsunami Warning Center (HL-NTWC), which is a unit of the Institute of Geodynamics of the National Observatory of Athens (NOA-IG), was officially established in Greece by law in September 2010. It operates a 24/7 tsunami monitoring service for Greece and the eastern Mediterranean Sea, providing warning messages to the General Secretariat for Civil Protection in Greece. Since August 2012, HL-NTWC acts as Candidate Tsunami Service Provider (CTSP) in the framework of the North-Eastern Atlantic, the Mediterranean and connected seas Tsunami Warning System (NEAMTWS) of the IOC/UNESCO providing tsunami messages to a large number of subscribers. The HL-NTWC function is based on the national seismograph and tide gauge networks of NOA-IG and incorporates several data bases, algorithms and computational tools. Collaboration with top class research institutions in the framework of important EC funded tsunami research projects strengthens the scientific background of the center. Tests, exercises and training of the duty officers involved in the 24/7 operation of the HL-NTWC are carried on constantly, in order to maintain a high level of readiness and response in case of emergency. In its operational life since August 2012 the HL-NTWC has timely issued tsunami warning messages for 14 potentially tsunamigenic earthquake events. Keywords: tsunami warning, operational center, risk mitigation, North-Eastern Atlantic, Mediterranean.
\end{abstract}

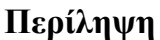

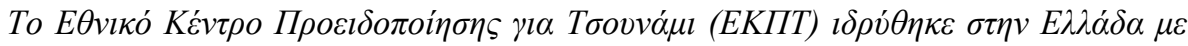

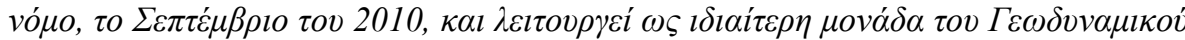

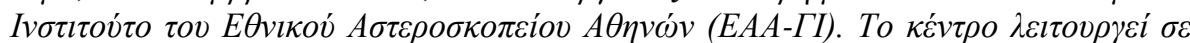

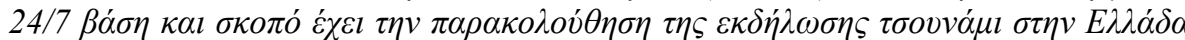

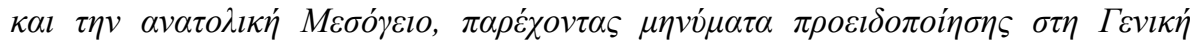

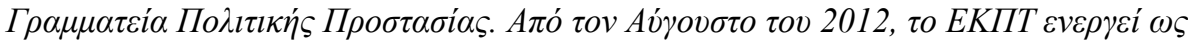

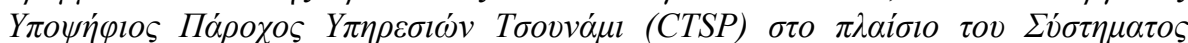

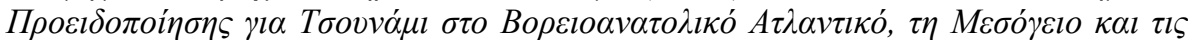

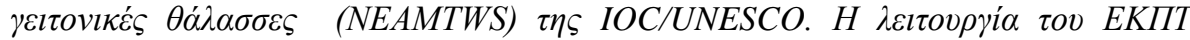

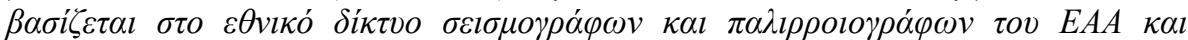
$\alpha \xi ı$ lo

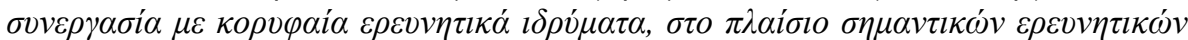

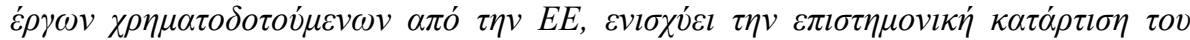

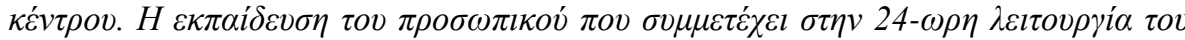




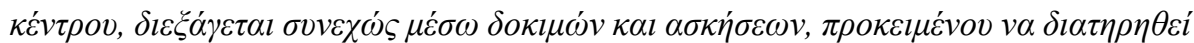

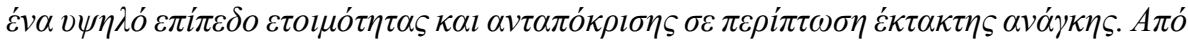

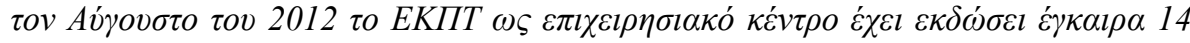

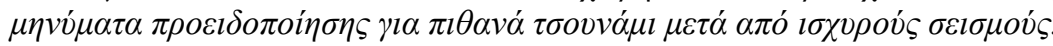

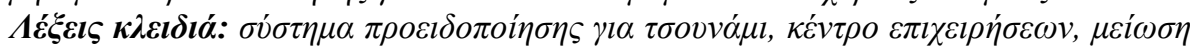

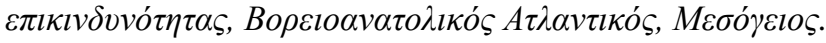

\section{Introduction}

The 26 December 2004 Indian Ocean tsunami, in which over 250,000 lives were lost around the Indian Ocean region, has brought the attention of the international community to the need for mitigating tsunami risk in various parts of the world given that only in the Pacific Ocean a tsunami warning system was already in place. The Intergovernmental Oceanographic Commission of UNESCO (IOC-UNESCO) received a mandate from the international community to coordinate the establishment of tsunami warning systems in the Indian Ocean, in the Caribbean as well as in the North-Eastern Atlantic, the Mediterranean and connected seas (NEAM region). As regards NEAM, the tsunami frequency is not so much high as the earthquake frequency is. However, many historical, disastrous tsunami events have been documented (e.g. Papadopoulos et al., 2014). During 2005 the IOC General Assembly formally established the Intergovernmental Coordination Group (ICG) for the NEAM Tsunami Early Warning and Mitigation System (NEAMTWS). The guidelines for the NEAMTWS activities are compiled in the NEAMTWS Implementation Plan and other documents. An extensive review of the tsunami phenomena in the NEAM region, the associated hazards, as well as the current status of NEAMTWS, was recently published (Papadopoulos, 2015).

A first effort to develop a local tsunami warning system in the western segment of the Hellenic Arc was undertaken in the frame of the EC funded GITEC project (Papadopoulos, 2003a). From the very beginning of the IOC's initiative in 2005, the Institute of Geodynamics of the National Observatory of Athens (NOA-IG) was actively engaged in planning and developing the NEAMTWS preparing gradually infrastructures, data bases and computational tools. The Hellenic National Tsunami Warning Center (HL-NTWC) was officially established by Law in September 2010. The HL-NTWC is a particular unit of the NOA-IG. In August 2012, the HL-NTWC was declared as operational tsunami center, offering tsunami warning at the national level and tsunami watch services within the frame of the NEAMTWS acting as Candidate Tsunami Service Provider in the frame of NEAMTWS/IOC/UNESCO. It operates on a 24/7 basis, providing monitoring and tsunami warning services in the region of Greece and the eastern Mediterranean. The HL-NTWC Operational Centre is linked to the Civil Protection Operational Centre and serves as the official alerting agency to the General Secretariat for Civil Protection in Greece as regards tsunami warning operations.

\section{Infrastructure and development}

The HL-NTWC operates in the same control room along with the seismic monitoring and is supported by the same staff that performs daily seismic analysis and monitoring. The HL-NTWC function is based on the national seismograph and tide gauge systems of NOA-IG and incorporates several data bases, algorithms and computational tools, including the TAT (Tsunami Analysis Tool) which has been provided by the Joint Research Center of the European Commission (EC-JRC) at Ispra.

The core network supporting the HL-NTWC is the Hellenic Unified Seismic Network (HUSN) (Figure 1). NOA coordinates HUSN which incorporates more than 150 seismic stations contributed by the NOA's Hellenic Seismic Network (HL, 49 BB 3-component stations; 22 stations are also equipped with a co-located strong motion sensor) as well as by local networks operated by University Seismic Networks (HP-Patras, HT-Thessaloniki, HA-Athens). In addition, seismic stations located in Greece and in neighboring countries, that belong to affiliated collaborative partner networks, such as GEOFON (GE), MEDNET (MN), INGV (IV), KOERI (KO) and Cyprus (CQ), are also included in the near real-time acquisition and storage as it is performed at NOA's HL (Figure 
1). The recorded data by HL are sent to the National Data Center (NDC) via the SeedLink protocol where they are processed automatically (SeisComp3 analysis suite) and analyzed manually by operators in a 24/7 mode (Nanometrics processing suite). The software package for earthquake detection and automatic location that is used at NOA-IG (SeisComP3), also utilizes strong motion stations. Moreover, the capability of real time strong motion networks for moment tensor estimations and their implementation for use in warning operations is under investigation.

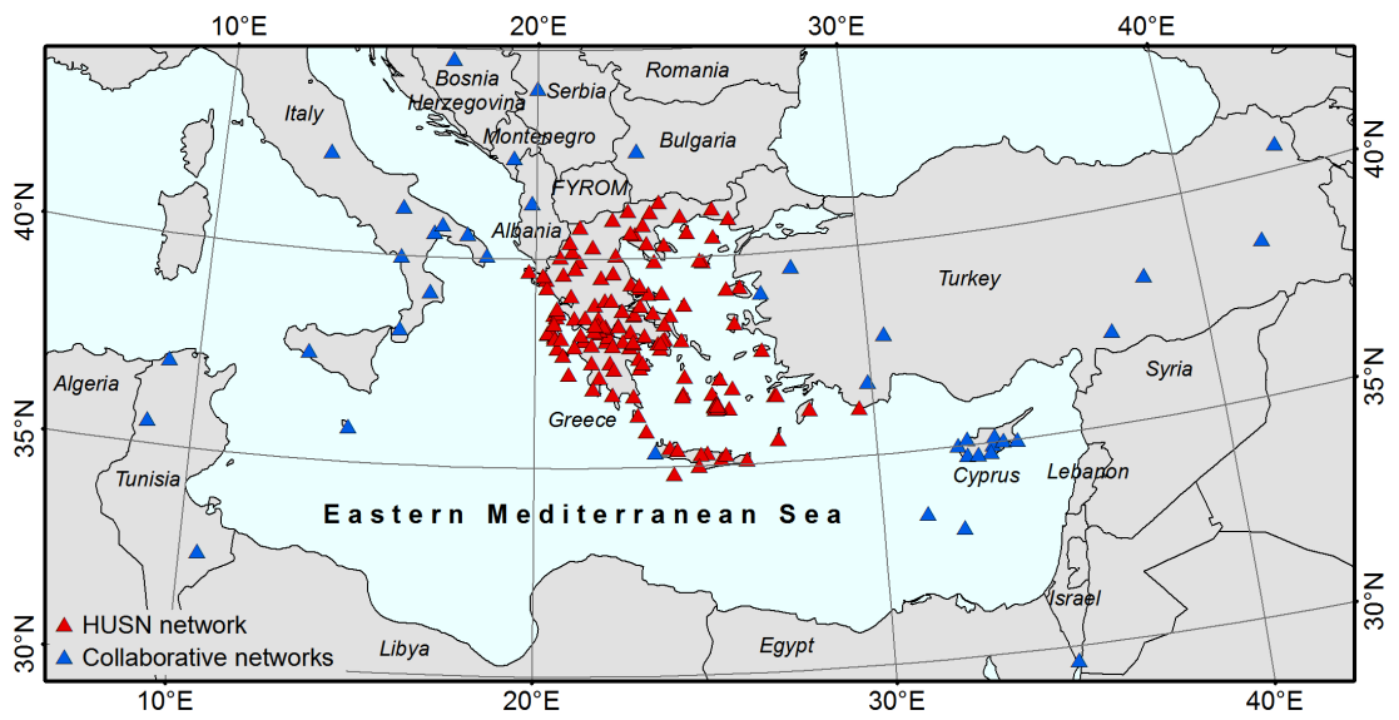

Figure 1 - Map showing seismic stations being available online at NOA-IG.

For the control of the sea level changes the HL-NTWC is supported by the tide gauge network, which has been developed in the last years and is rapidly expanding (Figure 2). The real-time tide gauge network of NOA, along with one tide-gauge station of ITSAK, currently consists of 17 realtime stations (radar type and/or pressure type) with sampling rate of $\sim 1 / 30 \mathrm{sec}$ or less which is suitable to record tsunami waves and to support tsunami operations. Three collaborative tide gauge stations have been installed in June 2013 in Koroni, Kithira and Paleochora (SW Crete), operated in cooperation with the JRC. Data from these stations are available to both HL-NTWC and JRC in real time. Each station comprises two independent sensors, one pressure and one microwave radar sensor and a co-located cGPS. During 2013, in the frame of several projects, NOA-IG installed another set of four tide gauge stations equipped with microwave sensors, in the islands of Santorini, Kerkyra (Corfu) and Rhodes (2 stations). In addition, a tide gauge station which was installed in Thessaloniki by ITSAK is linked with the HL-NTWC transmitting data in real time. By the end of 2015, within the frame of the national project "KRIPIS", the HL-NTWC installed another 8 stations, five in various localities along the Hellenic Arc, two in the Corinth Gulf and one in Samothraki Isl., North Aegean Sea. A third station was installed in Corinth Gulf in collaboration with JRC. Moreover, tide gauge stations operated by the Hellenic Navy Hydrographic Service (HNHS) are accessible via ftp communication procedure, when they are available. The installation of more stations in the near future has been scheduled. In addition, NOA receives also records of tide gauges belonging to other organizations in Italy and Egypt.

The main software tools that are used by the duty officers in HL-NTWC are the SeisComP3 and the Tsunami Analysis Tool (TAT). SeisComP3 is a widely distributed software package for seismological data acquisition and real-time data exchange. It is designed as a high standard fully automatic data acquisition and a near real-time data processing tool including earthquake detection and automatic location, quality control, and dissemination of event alerts. In the context of the GITEWS project (German-Indonesia Tsunami Early Warning System) additional functionalities were implemented to fulfil the requirements of 24/7 early warning control centers. 
On the other hand, in the framework of the cooperation with JRC, TAT provides a dedicated Decision Support Tool that allows the analysis of the tsunami events. It is directly linked to scenario databases that enable HL-NTWC duty officer to estimate wave arrival times and wave heights near the coast. It also has message dissemination capabilities of the various tsunami warning messages. An important component in the Tsunami analysis that is provided by TAT is the online availability of sea level measurements. Basic waveform filtering and analysis, as well as comparison with simulation data are available.

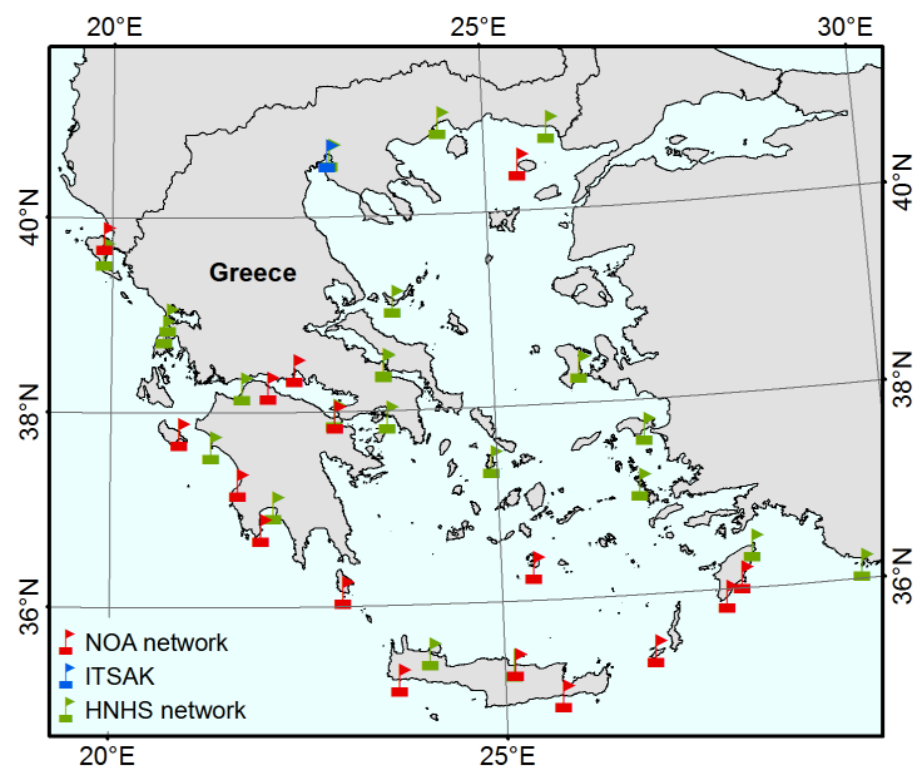

Figure 2 - Tide gauge networks utilized by HL-NTWC.

Tsunami message dissemination is achieved through a scripting module that has been developed in house, following Tsunami Analysis Tool messaging output. This module gives the user the opportunity to send simultaneously all three types of messages, i.e. e-mail, fax and GTS, the last through the Hellenic National Meteorological Service (HNMS) via the dedicated VPN link between HNMS and NOA operating centers. The SMS technology has also been used during the last tsunami exercise (NEAMWAVE14) and the extended Communication Tests.

Future infrastructure developments to support further the operation services provided by the HLNTWC include expansion of the seismic network, addition of more accelerographic stations, deployment of new tide gauge stations for tsunami watch purposes, computation of pre-simulated tsunami scenarios for the extension of the database in use and trial of newly established software modules for tsunami and earthquake alerting (i.e. Early-Est, SeisComP3 etc.).

\section{Involvement in scientific activities}

The newly formed HL-NTWC takes advantage of participating in important EC funded research projects in the field of tsunamis, like TRANSFER, SCHEMA and SEAHELARC (FP6), NEARTOWARN, TSUMAP-NEAM and ARISTOTLE (DG-ECHO, 2012-2013 and 2016-2017), ASTARTE and ZIP (FP7). Outcomes and gained knowledge from collaboration with top class research institutions that produce important results in the research front in Europe, are exploited towards the development of a top class Operational Center, useful for Civil Protection purposes in regions in need, including Greece.

Scientific research is a top priority for the HL-NTWC. Tsunami research aims not only to improve scientific knowledge but also to reinforce and support the HL-NTWC. Research activities include 
the compilation of tsunami catalogues and web GIS databases, studies of the generation mechanisms and numerical simulations of the generation, propagation and inundation of tsunami waves, tsunami source studies, investigation of palaeotsunami events with geological methods, development of tsunami intensity scales and hazard assessment methods as well as the development of local tsunami warning systems, such as the one that operates in Rhodes after its organization in the frame of the NEARTOWARN project.

\section{Tsunami watch operations}

The corner-stone for the operational part of the NEAMTWS are the National Tsunami Warning Centers (NTWCs) that have accepted to provide tsunami services within the frame of NEAMTWS. Since summer 2012, the national tsunami warning centers of France (CENALT), Greece (HLNTWC) and Turkey (KOERI) started to provide such services. During 2014, the Italian Tsunami Warning Center (CAT) established in INGV was added also as a center providing tsunami services. The above four tsunami centers are formally still named "Candidate Tsunami Service Providers (CTSPs)" since the procedure of their accreditation has not been completed yet, but is expected to be completed soon. In practice, those centers already act operationally at both the national level and at the NEAM level. Also, Germany has offered to provide backup for data collection and processing through the GFZ technological infrastructures. In Portugal, the national tsunami center has been established in IPMA at Lisbon. It is expected that in the near future IPMA will join the group of national centers providing tsunami services within the frame of NEAMTWS.

It is understood that in their national roles the above tsunami centers, including HL-NTWC, act according to the respective national mandates and instructions which are adjusted to the national administrative needs that may be different from the ones at the NEAMTWS level. However, from the technical point of view the standards that the national centers follow at national level are the same with those at the level of NEAMTWS. In fact, all the centers that provide tsunami services have in common some standard characteristics decided by the ICG/NEAMTWS, such as the operation on 24/7 basis of national seismograph systems and tide gauge networks as well as expertise in seismic and tsunami monitoring. The HL-NTWC already operates as CTSP for the Eastern Mediterranean and is prepared to be accredited soon. It disseminates tsunami warning messages to 17 agencies from 12 Member States, to three international bodies (IOC/UNESCO, ERCC-EC, JRC) as well as to the Greek General Secretary for Civil Protection (Figure 3).

The procedure which is followed to issue tsunami alerting messages by the HL-NTWC and the other CTSP's have as follows. As soon as an earthquake of minimum magnitude 5.5 has been generated under the sea or close to the coastal zones, the HL-NTWC is responsible to process and analyze earthquake data for the rapid initial assessment as a basis for the alert system. The basic seismic information which should be determined as soon as possible after the generation of an earthquake are the main focal parameters of the seismic event, that is the earthquake origin time, epicenter, focal depth and magnitude. This is achieved by the NOA's automatic system within about 3 min from the earthquake origin time.

Since immediately after the earthquake generation it is not known if a tsunami has been generated or not, a tool which is called "Decision Matrix" is used to decide the type of tsunami message that should be formulated and disseminated. A "Decision Matrix" is a set of empirical rules, regarding the possibility for a tsunami to have been generated or not according to the location of the earthquake epicenter as well as to the earthquake focal depth and magnitude. After long technical discussions within the working groups that support the ICG/NEAMTWS, it was decided that two similar in their structure but different in the numerical values "Decision Matrices" are appropriate to use, one for the North East Atlantic region and another for the Mediterranean basin. In Table 1 one may see that the tsunami severity (threat) level predicted by the "Decision Matrices" scales with the earthquake magnitude range. As a consequence, three levels of tsunami messages could be produced with the increase of the wave severity: Tsunami Information, Tsunami Advisory, Tsunami Watch. At the 
same time, the magnitude range determines also the maximum distance at which tsunami impact is likely to be caused in the coasts. From this point of view local, regional and basin-wide tsunami message types are considered. In the Mediterranean, local distance means no more than $100 \mathrm{~km}$, regional distance has been decided to be up to $400 \mathrm{~km}$, while basin-wide distance is meant as the spatial field of possible tsunami impact beyond $400 \mathrm{~km}$. The assessment of the possible tsunami wave severity is summarized in Table 2.

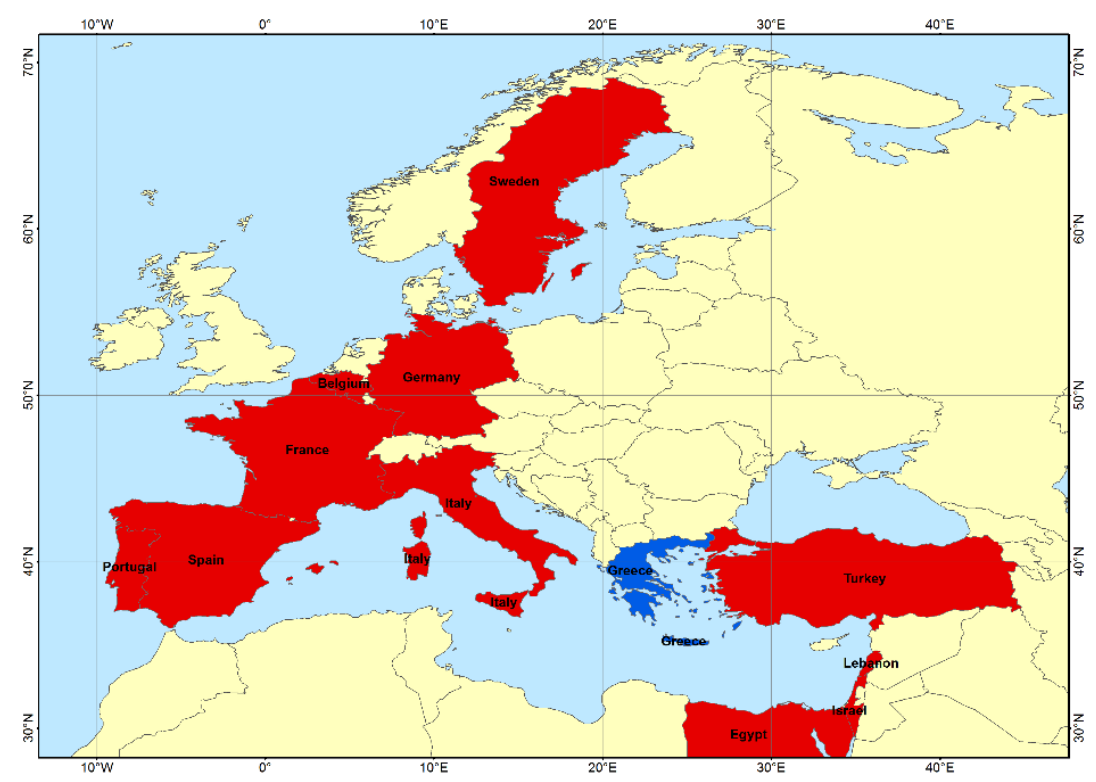

Figure 3 - Subscribers to HL-NTWC of NOA tsunami warning service.

However, the interest is not restricted only in making decision if a tsunami has been potentially generated and to assess its overall severity. On the contrary, it is of alerting importance to compute also the arrival time of the tsunami in a number of coastal forecast points that have been determined officially by the NEAMTWS country-members. Therefore, besides earthquake focal parameters, a standardized tsunami alerting message informs the recipients about the type of the tsunami message, using combinations between the various severity types (Information, Advisory, Watch) and the types of possible impact distance (Local, Regional, Basin-wide), as well as the calculated arrival time in a number of official forecast points. At the present stage of development the HL-NTWC and the other CTSP's release tsunami messages in about $10 \mathrm{~min}$ after the earthquake origin time. However, after the Lefkada Isl. earthquake (Mw6.4) of 17 November 2015, the HL-NTWC issued its first tsunami bulletin only $5 \mathrm{~min}$ after the earthquake origin time.

The next step in the alerting procedure is to collect, record, process and analyze sea level data for confirming and monitoring the tsunami or for cancelling elements of the alert message. If a tsunami occurrence has been confirmed by the sea level data then the tsunami message should be updated with the relevant information and resend as soon as possible. This is the case of the Lefkada 2015 case, when an ongoing tsunami message was issued after the record of a tsunami-like sea oscillation of peak-to-peak amplitude of $20 \mathrm{~cm}$ in the Crotone tide-gauge station in Italy. If needed, this procedure may repeat more than once. If, however, no tsunami generation is confirmed, then a tsunami cancellation message is issued and disseminated. It is noteworthy that no responsibility areas have been determined for each one of the four centers operating in the frame of NEAMTWS. Therefore, sending and receiving tsunami messages is performed only on a subscription basis. 
Table 1 - Decision Matrix for the Mediterranean basin, proposed by the ICG/NEAMTWS in November 2010.

\begin{tabular}{|c|c|c|c|c|c|c|}
\hline \multicolumn{7}{|c|}{ Decision Matrix for the Mediterranean } \\
\hline \multirow{2}{*}{$\begin{array}{l}\text { Focal } \\
\text { Depth }\end{array}$} & \multirow{2}{*}{$\begin{array}{c}\text { Epicenter } \\
\text { Location }\end{array}$} & \multirow[t]{2}{*}{$\mathrm{Mw}$} & \multirow[t]{2}{*}{ Tsunami Potential } & \multicolumn{3}{|c|}{ Tsunami Message Type } \\
\hline & & & & Local & Regional & Basin \\
\hline \multirow{4}{*}{$<100 \mathrm{~km}$} & \multirow{2}{*}{$\begin{array}{l}\text { Offshore } \\
\text { or close to } \\
\text { the coast } \\
\text { ( } \leq 40 \mathrm{~km} \\
\text { inland) }\end{array}$} & $\begin{array}{l}>5.5- \\
\leq 6.0\end{array}$ & $\begin{array}{l}\text { Weak potential for } \\
\text { local tsunami }\end{array}$ & Advisory & $\begin{array}{l}\text { Informati } \\
\text { on }\end{array}$ & $\begin{array}{l}\text { Informati } \\
\text { on }\end{array}$ \\
\hline & & $\begin{array}{l}>6.0- \\
\leq 6.5\end{array}$ & $\begin{array}{l}\text { Potential for a } \\
\text { destructive local } \\
\text { tsunami }(<100 \mathrm{~km})\end{array}$ & Watch & Advisory & $\begin{array}{l}\text { Informati } \\
\text { on }\end{array}$ \\
\hline & \multirow{2}{*}{$\begin{array}{l}\text { Offshore } \\
\text { or close to } \\
\text { the coast } \\
\text { ( } \leq 100 \mathrm{~km} \\
\text { inland) }\end{array}$} & $\begin{array}{l}>6.5 \\
\leq 7.0\end{array}$ & $\begin{array}{l}\text { Potential for a } \\
\text { destructive regional } \\
\text { tsunami }(<400 \mathrm{~km})\end{array}$ & Watch & Watch & Advisory \\
\hline & & $>7.0$ & $\begin{array}{l}\text { Potential for a } \\
\text { destructive basin- } \\
\text { wide tsunami }\end{array}$ & Watch & Watch & Watch \\
\hline$\geq 100 \mathrm{~km}$ & $\begin{array}{l}\text { Offshore } \\
\text { or inland } \\
\leq 100 \mathrm{~km}\end{array}$ & $>5.5$ & Nil & $\begin{array}{l}\text { Informati } \\
\text { on }\end{array}$ & $\begin{array}{l}\text { Informati } \\
\text { on }\end{array}$ & $\begin{array}{l}\text { Informati } \\
\text { on }\end{array}$ \\
\hline
\end{tabular}

During the nearly three years of operation, the HL-NTWC has timely issued tsunami warning messages, and the respective cancellation messages, after 14 potentially tsunamigenic earthquakes (Table 3). One may see that in 12 out of 14 cases only Information bulletins were issued. In one case (n. 13 in Table 3) Watch bulletin was issued, but no tsunami was observed. In the last case (n. 14 in Table 3), a Watch bulletin was issued and a tsunami-like tide record was documented, as mentioned earlier. Further indices for the evaluation of the performance of tsunami bulletins issued by the CTSPs are under elaboration by the Task Team on Tsunami Operations of ICG/NEAMTWS.

Table 2 - Tsunami message type and respective tsunami wave severity.

\begin{tabular}{|l|l|l|}
\hline \multicolumn{1}{|c|}{ Message type } & \multicolumn{1}{|c|}{ Tsunami Wave } & \multicolumn{1}{c|}{ Effects on the coast } \\
\hline Tsunami Watch & $\begin{array}{l}\text { Tsunami wave height greater } \\
\text { than } 0.5 \mathrm{~m} \text { and/or tsunami run- } \\
\text { up greater than } 1 \mathrm{~m}\end{array}$ & $\begin{array}{l}\text { Coastal inundation, potentially } \\
\text { including all the phenomena } \\
\text { described as potential coastal } \\
\text { effects corresponding to tsunami } \\
\text { advisory }\end{array}$ \\
\hline Tsunami Advisory & $\begin{array}{l}\text { Tsunami wave height less than } \\
0.5 \mathrm{~m} \text { but larger than } 0.2 \mathrm{~m} \text { and/ } \\
\text { or tsunami run-up less than } 1 \mathrm{~m}\end{array}$ & $\begin{array}{l}\text { Currents, bore, recession, damage } \\
\text { in harbors, small inundation on } \\
\text { beaches }\end{array}$ \\
\hline Tsunami Information & \multicolumn{2}{|l|}{ No tsunami threat } \\
\hline
\end{tabular}

It should be noted that currently the HL-NTWC does not cover the Corinth Gulf, Central Greece, although the frequency of local tsunami generation is relatively high there (Papadopoulos, 2003; Stefatos et al., 2006; Tselentis et al., 2006). The reason is that the Corinth Gulf covers only a very limited geographic area being of about $115 \mathrm{~km}$ in length and of $30 \mathrm{~km}$ maximum width. However, a special "Decision Matrix" is under elaboration aiming to close this gap in the tsunami warning operations in Greece. It is also noteworthy that the NEAMTWS, and consequently the HL-NTWC, operate only for tsunamis generated by earthquakes. Tsunamis caused by aseismic landslides or volcanic processes are beyond the current operation status of NEAMTWS. 
Table 3 - Summary of NOA HL-NTWC tsunami warning bulletins issued from August 2012 up to $31^{\text {st }}$ December 2015.

\begin{tabular}{|c|c|c|c|c|}
\hline No. & $\begin{array}{c}\text { Time (UTC) } \\
\text { Date }\end{array}$ & Region & Final $M_{w}$ & $\begin{array}{l}\text { EQ Bulletins Issued } \\
\text { (preliminary NOA } \\
\text { magnitude was used) }\end{array}$ \\
\hline 1 & $\begin{array}{c}14: 18: 08 \\
8 \text { Jan } 2013\end{array}$ & $\begin{array}{l}\text { N. Aegean Sea, Limnos Isl. } \\
\text { (GR) }\end{array}$ & 5.7 & $\begin{array}{c}\text { Information } \\
(5.8)\end{array}$ \\
\hline 2 & $\begin{array}{c}\text { 16:11:02 } \\
15 \text { Jun } 2013\end{array}$ & Crete Isl. (GR) & 6.1 & $\begin{array}{c}\text { Information } \\
(5.9)\end{array}$ \\
\hline 3 & $\begin{array}{c}21: 39: 04 \\
16 \text { Jun } 2013\end{array}$ & Crete Isl. (GR) & 5.8 & $\begin{array}{c}\text { Information } \\
(5.7)\end{array}$ \\
\hline 4 & $\begin{array}{c}13: 11: 53 \\
12 \text { Oct } 2013\end{array}$ & W. Crete Isl. (GR) & 6.4 & $\begin{array}{l}\text { Information } \\
(6.3)\end{array}$ \\
\hline 5 & $\begin{array}{c}15: 21: 05 \\
28 \text { Dec } 2013\end{array}$ & Cyprus region & 5.9 & $\begin{array}{l}\text { Information } \\
\text { (5.9 EMSC) }\end{array}$ \\
\hline 6 & $\begin{array}{c}18: 45: 08 \\
26 \text { Jan } 2014 \\
\end{array}$ & $\begin{array}{l}\text { Ionian Sea, } \\
\text { Cephalonia Isl. (GR) }\end{array}$ & 5.3 & $\begin{array}{c}\text { Information } \\
(5.9)\end{array}$ \\
\hline 7 & $\begin{array}{c}03: 08: 44 \\
3 \text { Feb 2014 }\end{array}$ & $\begin{array}{l}\text { Ionian Sea, } \\
\text { Cephalonia Isl. (GR) }\end{array}$ & 5.9 & $\begin{array}{c}\text { Information } \\
(5.9) \\
\end{array}$ \\
\hline 8 & $\begin{array}{c}\text { 20:08:07 } \\
4 \text { Apr 2014 }\end{array}$ & $\begin{array}{l}\text { Aegean Sea, } \\
\text { Hydra Isl. (GR) }\end{array}$ & 5.4 & $\begin{array}{l}\text { Information } \\
(5.6)\end{array}$ \\
\hline 9 & $\begin{array}{c}09: 25: 02 \\
24 \text { May2014 } \\
\end{array}$ & $\begin{array}{l}\text { N. Aegean Sea, Samothraki } \\
\text { Isl. (GR) }\end{array}$ & 6.8 & $\begin{array}{c}\text { Information } \\
(6.0)\end{array}$ \\
\hline 10 & $\begin{array}{c}03: 45: 05 \\
29 \text { Aug } 2014\end{array}$ & $\begin{array}{l}\text { S. Aegean Sea, } \\
\text { SE Peloponnesus (GR) }\end{array}$ & 5.8 & $\begin{array}{c}\text { Information } \\
(5.8)\end{array}$ \\
\hline 11 & $\begin{array}{c}\text { 08:52:12 } \\
15 \text { Apr } 2015\end{array}$ & Cyprus region & 5.3 & $\begin{array}{c}\text { Information } \\
(5.6)\end{array}$ \\
\hline 12 & $\begin{array}{c}18: 07: 44 \\
16 \text { Apr 2015 } \\
\end{array}$ & Kasos Isl. (GR) & 6.0 & $\begin{array}{c}\text { Watch/Cancel } \\
(6.1) \\
\end{array}$ \\
\hline 13 & $\begin{array}{c}02: 05: 42 \\
17 \text { Apr 2015 }\end{array}$ & Kasos Isl. (GR) & 5.4 & $\begin{array}{c}\text { Information } \\
(5.6) \\
\end{array}$ \\
\hline 14 & $\begin{array}{c}\text { 07:10:07 } \\
17 \text { Nov } 2015\end{array}$ & Lefkas Isl. (GR) & 6.4 & $\begin{array}{c}\text { Watch/Ongoing/End } \\
(6.0)\end{array}$ \\
\hline
\end{tabular}

\subsection{Communication Tests and Exercises}

All agencies that are involved in tsunami warning and mitigation must keep a high level of readiness. In order to be able to maintain such an operational level of readiness and especially for infrequent events such as tsunamis, TWP's, NTWC's and emergency agencies must regularly practice their response procedures to ensure that vital communication links work flawlessly, and that agencies and response personnel know the roles that they will need to play during an actual event. For this purpose, HL-NTWC participates in monthly communication tests and exercises organized by the IOC, in order to periodically verify and keep its readiness. Every first week of each month, it conducts regular communication tests and also participates in tests that are organized by other CTSPs. Also, the HL-NTWC effectively conducted the $3^{\text {rd }}$ and $6^{\text {th }}$ Enlarged Communication Test Exercises in October 2013 and July 2015, respectively, with the participation of 31 counties and 40 agencies.

Under the coordination of ICG/NEAMTWS/IOC, extended system testing exercises are also conducted based on pre-simulated tsunami scenarios. HL-NTWC successfully participated in the 
NEAMWAVE12 exercise (November 2012), the first Tsunami Exercise in NEAM region, providing a scenario based on the 9 July 1956 Amorgos large tsunami (Okal et al., 2009). In October 2014, it also provided one of the four scenarios for NEAMWAVE14. The provided simulation was about the AD 21 July 365 western Crete large earthquake and tsunami event (e.g. Shaw et al., 2008) and was employed by the Emergency Response Coordination Centre of the European Commission (ECERCC) as an opportunity to test the internal procedures at the Union Civil Protection Mechanism (UCPM) and assess the capability of planning and activating the procedures for provision of international assistance to those affected countries which request it.

\section{Training initiatives}

Training of the duty officers involved in the 24/7 operation of the HL-NTWC is carried on constantly, since the operators are taking shifts. Talks and presentations are organized covering a wide range of topics, such as the operating procedures of a tsunami service provider, the operation of dedicated software (TAT, Seiscomp3 etc.) or of more scientific interest, such as earthquake and tsunami hazards and sea-level measurements.

Tsunami warning systems must go hand in hand with awareness and preparedness of the general public. Since it is impossible to reduce the frequency of tsunami occurrence, people in endangered coastlines have to be prepared and know what to do in case a tsunami warning has been issued by the national authorities. Therefore, HL-NTWC has actively taken part in the Tsunami Information Centre (NEAMTIC) initiative of IOC/UNESCO. Tsunami related educational material has been translated into Greek, in order to provide information on warning systems, risks and good practices with respect to tsunamis and other sea-level related hazards for civil protection agencies, disaster management organizations, decision makers, schools, industries in the coastal zone and the general public. This is to fulfil the increasing need to better educate communities about tsunami threats.

In parallel, other initiatives are already taking place, such as the Global Tsunami Informal Monitoring Service (GTIMS-1 for the years 2013-2014; GTIMS-2 for the years 2015-2016) under the coordination of JRC. The main aim of the GTIMS initiative is to maintain readiness among the centers that provide tsunami early warning services, to support the ERCC mechanism as well as to test the interoperability and cooperation capabilities between the various centers. This is achieved through a series of pseudo-messages and creation of rapid earthquake (and tsunami, if any) analysis reports for all the large $(\mathrm{M} \geq 7.0)$ earthquakes occurring globally. For GTMIS-1 the HL-NTWS produced and submitted 17 reports for an equal number of earthquake events.

\section{Acknowledgments}

The establishment, development and operation of the HL-NTWC has been made possible thanks to the support given by various national and international projects (some reported in the text) one of the most important being the IOC/UNESCO tsunami program. Thanks are due to the General Secretary for Civil Protection, to the General Secretary for Research and Technology, to JRC and DG-ECHO (European Commission), but above all to the dedicated staff of the Institute of Geodynamics. This is a contribution to the EU-FP7 tsunami research project ASTARTE (Assessment, Strategy And Risk Reduction for Tsunamis in Europe), grant agreement no: 603839, 2013-10-30.

\section{References}

Okal, E.A., Synolakis, C.E., Uslu, B., Kalligeris, N. and Voukouvalas, E., 2009. The 1956 earthquake and tsunami in Amorgos, Greece, Geophys. J. Int., 178, 1533-1554.

Papadopoulos, G.A., 2003a. Tsunami Hazard in the Eastern Mediterranean: Strong Earthquakes and Tsunamis in the Corinth Gulf, Central Greece, Natural Hazards, 29, 437-464. 
Papadopoulos, G.A., 2003b. A tsunami warning system in the SW Aegean Sea, Greece. In: Zschau, J. and Küppers, A.N., eds., Early Warning Systems for Natural Disaster Reduction, SpringerVerlag, 549-552.

Papadopoulos, G.A., 2015. Tsunamis in the European and Mediterranean region-From Historical Record to Risk Mitigation, Elsevier, 272 pp.

Papadopoulos, G.A., Gràcia, E., Urgeles, R., Sallares, V., De Martini, P.M., Pantosti, D., González, M., Yalciner, A.C., Mascle, J., Sakellariou, D., Salamon, A., Tinti, S., Karastathis, V., Fokaefs, A., Camerlenghi, A., Novikova, T. and Papageorgiou, A., 2014. Historical and pre-historical tsunamis in the Mediterranean and its connected seas: Geological signatures, generation mechanisms and coastal impacts, Marine Geology, 2014, doi: 10.1016/j.margeo.2014.04.014.

Shaw, B., Ambraseys, N.N., England, P.C., Floyd, M.A., Gorman, G.J., Higham, T.F.G., Jackson, J.A., Mocquet, J.M., Pain, C.C. and Piggott, M.D., 2008. Eastern Mediterranean tectonics and tsunami hazard inferred from the AD 365 earthquake, Nature Geoscience, 1, 268-276, doi: 10.1038/ngeo151.

Stefatos, A., Charalambakis, M., Papatheodorou, G. and Ferentinos, G., 2006. Tsunamigenic sources in an active European half-graben (Gulf of Corinth, Central Greece), Marine Geology, 232, 35-47.

Tselentis, A., Gkika, F. and Sokos, E., 2006. Tsunami hazards associated with the Perachora fault at eastern Corinth Gulf, Greece, Bull. Seism. Soc. Am., 96, 1649-1661. 